\title{
OBSERVATION ON THE CHANGES OF THE ENDOCOCHLEAR \\ D.C. POTENTIAL UNDER TONE STIMULATION
}

\author{
By \\ Mirsuo NAKATSUKA \\ From the Department of Oto-Rhino-Laryngology Faulty of Medicine \\ Tohoku University of Sendai (Dircctor: Prof. Y. Tsuiki)
}

By piercing a microelectrode through roundwindow membrane, influence on the endocochlear d,c. potential of guinea pigs under acoustic stimulation was studied experimentally, and the following results were obtained.

1) By acoustic stimulation, changes of endocochlear d. c. potential were observed in both periand endolymphatic space, and both in per-and poststimulatory period in spite of duration and frequency of stimulus tone.

2) In endolymphatic space the endolymphatic d.c. potential decrease by tone stimulation.

The course of these changes were generally as follows: as the tone is begun the d.c. potential falls rectangurally and then exponentially decreases, and when the tone is stopped the potential rises rectangurally and then exponentially increases to the original value of the potential.

But sometimes even in normally (fresh preparation?) the endolymphatic d.c. potential increases responding to low frequency and weak intense sound.

3) The latency of these changes was very short as C.M. and could not measured.
4) The changing value of this potential was linear at weak intense sound, but over about $75 \mathrm{db}$ S.L. become nonlinear. Those value were larger than low frequency tone under same sensation level.

5) In perilymphatic space (scala tympani) the poalrity of this phenomenon was antagonistic and the value was smaller than in the endolymphatic space (about 1/8). The course of this phenomenon in perilymphatic space was like that of the endolymphatic space under low frequency tone, but un der higher frequency tone the wave form becomes similar to the envelop curve of the stimulus tone.

6) At asphyxia, changing value of this phenomenon becomes smaller as decrease of endolym. phatic potential, and defficiency of oxygen became higher, and this d.c. potential becomes negative relative to perilymphatic potential. Just at this time the polarity of this phenomenon changes to the opposit side. From these results author considers the Summating Potential to be the changes of endocochlear d.c. potential under tone stimulation and those changes are observed also in poststimulatory period.

\section{音刺戟による蝸牛内直流電位変動の観察}

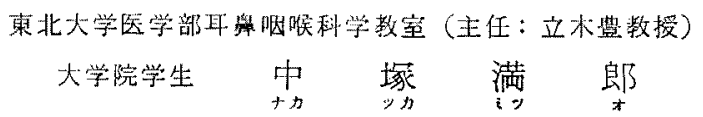

目次

\section{第1章緒管}

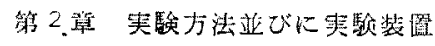

第 3 章 実虽成綘 


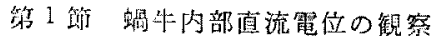

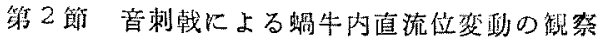

第 1 項 電位变動の経過

第 2 项 刺戟音王と区応電位との関倸

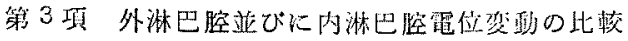

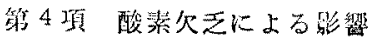

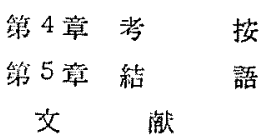

\section{第1章 緒 言}

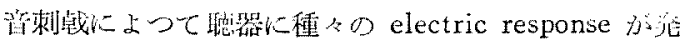

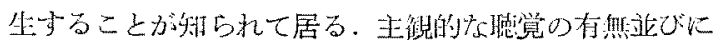

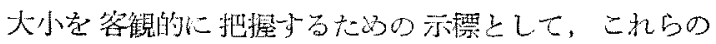
response 0女つ佔值は大きい. 其にこれらの response

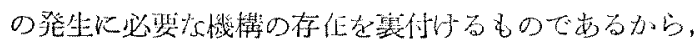

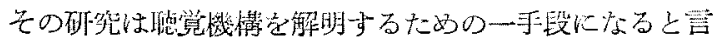
らことができるであるう。

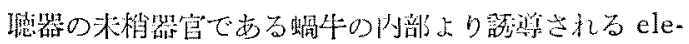
ctric response として, 玩任次の姐ものが湖告されて いる.

1. Cochlear microphonics (C.M.) : その名の如

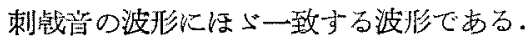

2. Whole nerve action potential (A.P.) : 袖紋一 般の活動䨨位と同しく栜波を呈し，刺战音の波仅に刘 し，同期性を不すことが知られている。

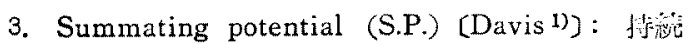
時間の短い音（ミリ秒単位）で刺钱した場合，音波昣の 包絡楾にほメ゙一致した波形を呈する。

4. d.c. fall (Békésy2) : 的骨牛内部の直流电位 (D. C. resting potential) が音響剌战によつて低下する現

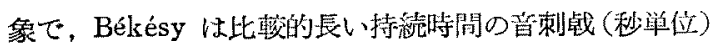
を用いて観察している。この波北は音没形の包絡線に活 ら゙一致した成分に, 刺战中增大し刺战終了後なお存在し

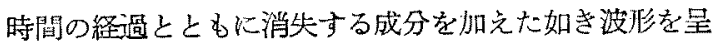
する。

上述の如く， Davis $の$ S.P. と Békésy $の$ dc fall

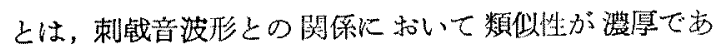
る.従つてこの再者は共に同種の霞位ではないかと言う

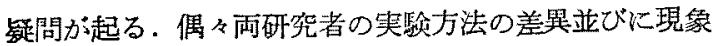
の解粎の相異によつてこのよらに一見別個の如き現象 として命名され，発表されているではするまいか。

例えば Davis は毛細胞を Generator と洘え，Bekésy は常時存在する直流電位の变化西举げている，若し同一
の現象であるとすれば、これらの現象を解明すくく西に

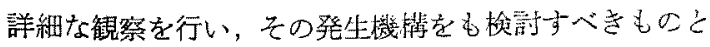
考光次の上らな实雅を淮めた。

\section{第 2 章 実験方法並びに実験装置}

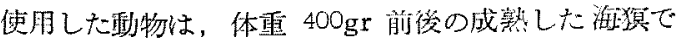

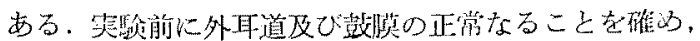
又プライェル反射陽性のるのを使用した。

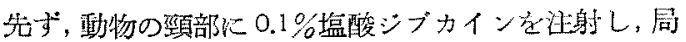
听㑣酶の下に，気管切開老施行し，カラス管カニューレ

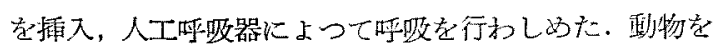

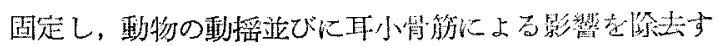

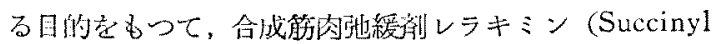

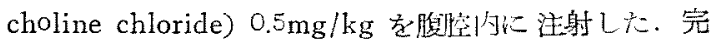

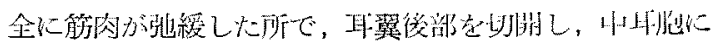

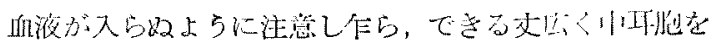
时放した。

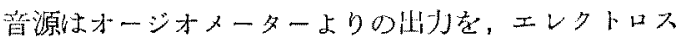

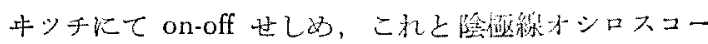

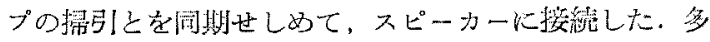

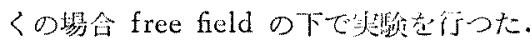

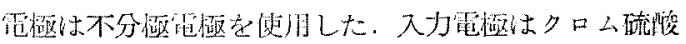

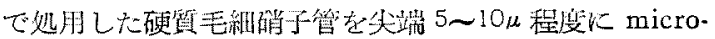

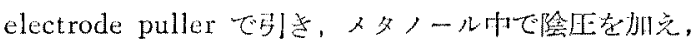

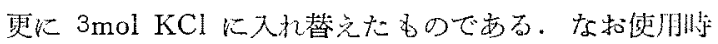

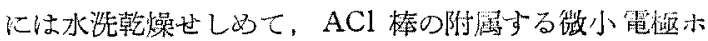

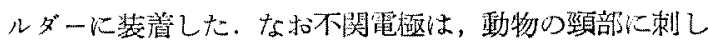
使用した。

增幅器は，本寒鈳で対象とする笪位の性質上周波数特 性の広い，又高感度の直流增湢器を使用した。電骤搑入 時に埂宜上チョツパー㤠直流增幅器をペンオシログラ

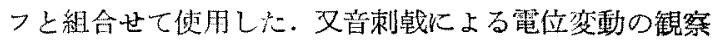
には、直結式直流堦幅器と二現象オシロスコープとを組 合せて胃象と刺战音の波形とを同侍に観察し，写真撮影 によりこれを記録した。

電柾搜入の方法は，開放した中耳胞の中に正円管部が 良く䚁察できるょらに動物を固定し，立体顕微鏡の下 に，マイクロマニプレーターに装渞した入力電極の失端 部を正円穴膜にのせ，正円空を通して豉室階の外淋巴， 更に基礎膜を穿孔して，中央階内湘巴腔へと䉓硬を推進 せしめた。

\section{第 3 章 実験 成 綪}

第1 算 蝸牛内直流電位の観案

既述の如き方法によつて, 蝸牛内部の直流電位の湘定 
を行つたこれれは先ず管点の汽定が閣題となるが，著

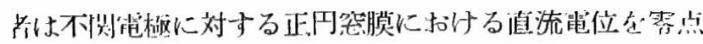
と汽めて，これに刘与る蝸牛内部の肉们を比較測定し た、マイクロマニブレーターに装着した微小白極を進め て，その矢端部が正円空膜を破り，鼓室階の外淋巴腔に 達しても，認むべき電位の変動は微察されなかつた。こ れより更に電極を進めて, 蝸牛内部の電位を測定するの であるが，その進行の方向が適切であるならば，電楅尖 端部は基碟回転の基碟膜に到達することができる．更に は基礎膜を穿孔して, 中央階の内淋巴腔にも到達するこ とが可能である.

第 1 図はこのよらな方法によつて，蝸牛内部における 各部の直流電位を連続的に記録したものである．この記 録より次のようなことを読み取ることができる．鼓室階 外淋巴の電位が基線であり，電極を進めると，電位は突 然下向きに変動し, 外淋巴の電位に比較して約 $-80 \mathrm{mV}$ を示す この電位け基碟膜の細胞内電位を示するのであ り，電㥛の尖端部は基碟膜を通過しつ〉あるためのもの と考えられる．更に電極を進めると，突然電位は上向き 飞約 $150 \mathrm{mV}$ 变動し, 外淋巴腔の電位に対し, 約 +75 $\mathrm{mV}$ の電位を読み敢ることができる。このように電極 の插入の際に, positive の電位が出現することは, 電極 尖端部が基磷膜を穿孔し，中央階の内淋巴膑に到達した ১めと考えるこができる。

\section{第 1 図}

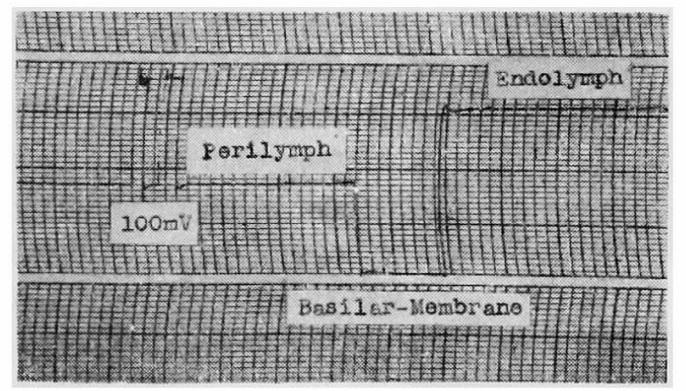

このょうな方法で測定した，螖牛内基碐回転部に批け る各部の直流䉓位は，基焚膜内でー70 $80 \mathrm{mV}$, 中央階 の内淋巴腔において +75〜85 mV であつた. 又若干の 動物においては，内淋巴の電位が $+100 \mathrm{mV}$ に達する ものも観察された.

以上述べた如き経過により, positiveな電位の出現に よつて，電極尖端部が中央階の内淋巴腔に到達したこと を確め，次のような実験を進めた。

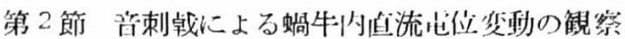
動物の外耳道より, 種々の周波数, 久種々の長さの刺

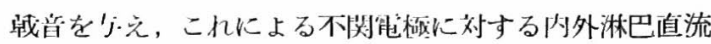

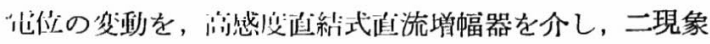
オシロスコープ上にて観察した。な㧊使用した刺皒音の 音圧は人耳間值上のデシベル数をもつて表した。

第 1 項 電位変動の経過

音刺战による内淋巴直流電位の変動は, 殆ど全ての周 波数の刺㦸音に対して, 又刺㦸音持緮時間の長短に拘ら ず観察できた. 第 2 図は, 1000c.p.s 75db, 0.4 秒間の音 刺战による内淋巴直流電位の変動を記録したものであ る. 図には三種の波形が記録されている.上段の波形 は，その原波形であり，中段の波形は，これを更に high cut filter を介して記録したものであり，下段の波 形は, 刺㦸音の電気的波形である. 刺㦸音とほ〉同波形

\section{第 2 図}

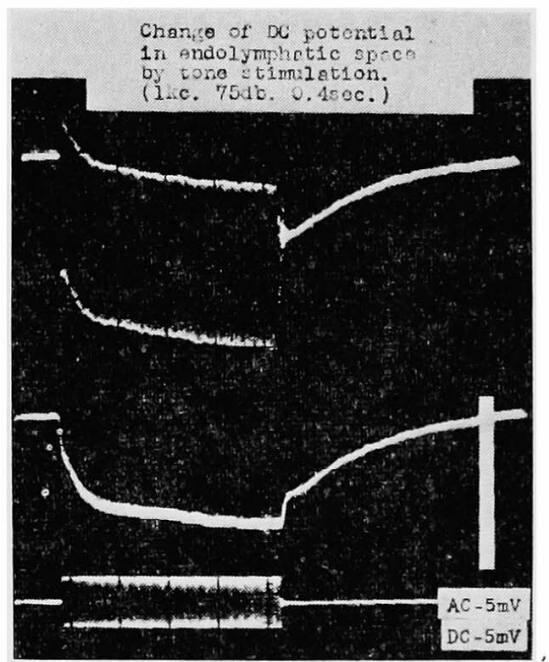

の電気的反応である C.M. が, 音刺㦸に対して蝸牛上り 誘導されることは周知のことであるが，図の上段の波形 において，下段の刺戰音のサインと一致して，帯状に見 られるのが，この刺战音に対する C.M. である. 更にこ

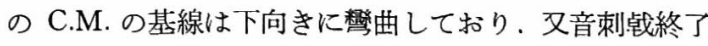
後, 徐々に元のレベルに戻る終過も読み取ることができ る. high cut filser を介して, C.M. をできる丈小さく して,この直流電位変動を読み易くしたものが, 中段の 波形である。このような方法によれば, 上段の波形で余 り明膫に見ることのできなからた音刺㦸の onset 並び に offset 時の現象も良く観察することができる。この 上らな電位変動は, 内淋巴直流電位の变動を示すもので 
あるから，音刺战によつて队淋巴の值流电位が低下する ことになる。

この経過は，音刺战の開始と同将に，直任的に低下 し, 以後始め急で後徐々に低下する凹的な曲線的経過を 示している. この曲線的経過は対数曲線を思はしめる. 又音刺㦸の終了と同時に電位は直解的に上舁し．以後は 凸的な曲線的経過をるつて元のレペルに戾つている。

このように音刺㦸に対する内淋巴直流電位変動の経過 は，第 3 図に示す如く，音刺战の onset, offset に見ら れる直角的成分と, 音刺㦸中並びに音刺㦸後に見られる 曲線的成分の二つの成分に分析できるょうに考㝋られ る.

第 4 図の波形は，二種の長さの異る刺战音 (3000 cps， 70db) に対する電位変動の波形を比較したものである.

第 3 図

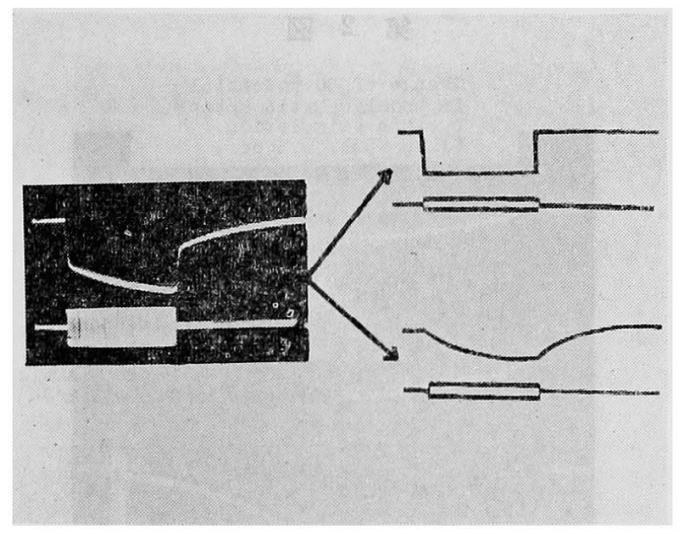

第 4 図

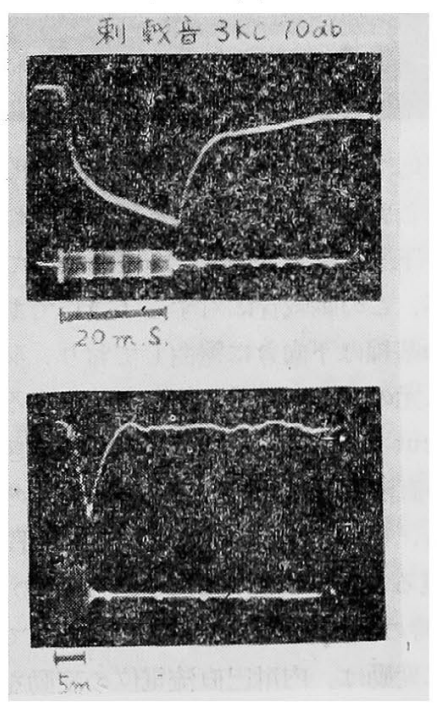

はに示寸 $20 \mathrm{msec}$ の音刺战に刘しては, 第 2 図に示した 之同様な絟過を示しているが，下に示す $5 \mathrm{msec}$ の学刺 战に対しては, その経過は異り、V型を示す これは前 述した曲線的経過はなく，直角的経過丈が観察された〉 めと考兄られ，更にこの経過は，基線に対して必ずしも 直角的でなく，ある傾斜をるつて，直線的に低下し又上 昇していることが知られる.

更にこの波形から，この電位 变動の latency を考兄 ると，音刺㦸で生ずる C.M. の発生と殆ど同時に，電位 が低下し始めることがわかる．このため，この電位変動 の latency は C.M. のそれと同じく測定不可能な程短 いものであると考党られる.

上述の如く, 音刺战による内淋巴直流電位の变動は. 一般にその直流電位の減少する方向に起ることが観察さ れる場合が多い，しかし正常な動物に执いても，時に音 刺战によつて, 直流電位の上算する経過も観察される. このような例においての $3000 \mathrm{cps} 20 \mathrm{msec}$ の音刺战に対 する電位变動の経過を第 5 四に示した。このような場合 の波形は，図の如く通常凹的な経過を示す曲線的成分 が，凸的な経過を示すことが锥察される．第 5 図上段の
第 5 図
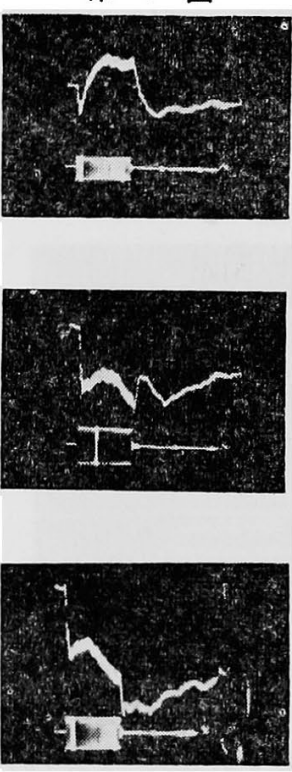
波形は，70db の音刺战による ものであり，直角的に低下した 電位は後凸的な経過を示し，基 線を越えて，（+）の電位を示 すに至る．中段の波形は $75 \mathrm{db}$ の音刺战によるものであり，凸 的経過は著明となるか，直解的 電位低下が大きいために（+) 側への変動は観察できぬ. 下段 の波形は $80 \mathrm{db}$ の音刺㦸による もので, 凸的経過の頂点以後の 低下る著明となる．更に音刺战 終了時の直角的成分は，上の図 と異り，反対に低下することが 見られた．この三種の波形にお いて凸的経過の頂点は, 音圧の 上昇につれて左側に移ることも 観察された。

以上述べたような電位変動は，弱い音圧又周波数の低 い音刺战に対して，多く見られる傾向があつた。

第 2 項 刺战音の音圧と反応電位との関係

音刺战に対する内淋巴直流電位の変動は, 前述の如 く，通常その直流電位が減少する力向に起るけれども， 
同一勁物においても，時に反対方向への電位变動が観察 されるものである．第6四はこのような場合の一例を示 した. 横軸测音の音圧, 縦軸にその反応電位を対数で 表わした. なお反応電位はこの現象の基線よりの最大変 動値をもつて表われた。

\section{第 6 図}

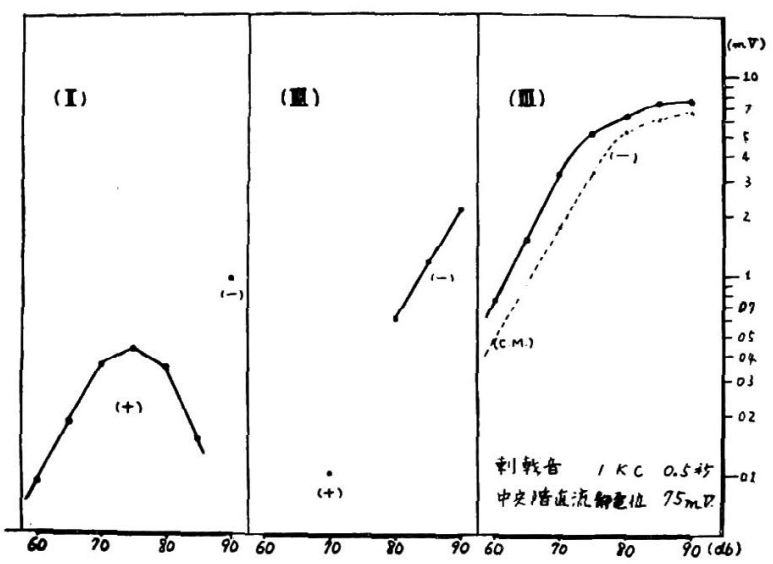

いても観察された。

第 7 図は各周波数 $(8 \mathrm{kc}, 6 \mathrm{kc}, 3 \mathrm{kc})$ の刺㦸音 $70 \mathrm{db}$ に対する鼓室階 (上段)，中央階 (下段) からの誘導し た電位変動を比較したものである。

基䂿膜を境とした雨者の電位変動の経過滰像的であ る. 鼓室階（外淋巴）の電位变動（上段）は刺战音の周 波数に上つてその波形はや」異り，立上りの部分に A.P. の波形も観察される。 $8 \mathrm{kc}$ の刺㦸音に対して は，短形波的電位変動を示して，直㑇的成分が著明 であり．曲線的な経過は観察し難い．この波形は刺 㦸音の波形の包絡線を示しているょうに思はれる. $6 \mathrm{kc}$ の刺战音に対しては, 刺战開始時の直角的成分 に比較して曲線的成分の経過が著明である. 3kcの 刺战音に対しては，曲線的な絟過が主であり，直角 的成分はや」不明瞭であることが観察できた。

更に，内外両淋巴に拈ける電位変動値は，約 $8: 1$ であつた．又刺棹音の周波数の高い程その变動值の 大きいことも知られた。
第6図（I）は電極插入直後の測定成績である.弱い 音に対しては, 内淋巴直流電位が上䄵する方向への現象 (+) が観察され, 刺践音の音圧を次第に強めると, こ の（十）の雹位変動も大きくなるが，75dbに拈いて最 大となり，これょり強い音王では，次第にその值も減少 し, $90 \mathrm{db}$ に至つては, 直流電位の減少する方向への電 位変動（一）が見られた。第6 図（II）はその後約 20 分過ぎて測定した成績である。(十) の電位変動が観察 されるのは $70 \mathrm{db}$ であり，それよりも弱い音圧並びに $75 \mathrm{db}$ の音王の刺战音に刘する電位変動梳, 测定不可能 な程に少さく, $80 \mathrm{db}$ 以上の强い音王の刺㲃音に対して は, (一) の变動を示し, 音王の上梨に比例してその変 動が直線的に增加することが観察された．第6図（III） は更に約 30 分後の測定値である. 現象は全て（一) の 電位変動を示し, 点線で示した C.M. の反応値とほぶ平 行して拈り，弱い音圧では直線的に上毕するが， $75 \mathrm{db}$ 以上の強い省刺战に対しては非直線的な增加を示すよ5 になる.この後約 20 分経て測定した成績は第6図（II） とほら゙同様であり，この反応值はその後変動なく安定す るものと考えられた。

第 3 項 外淋巴亚びに内淋巴電位変動の比䡬 音刺战に対する内淋巴道流西位の变動は既述の通りで

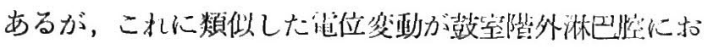

第 7 図

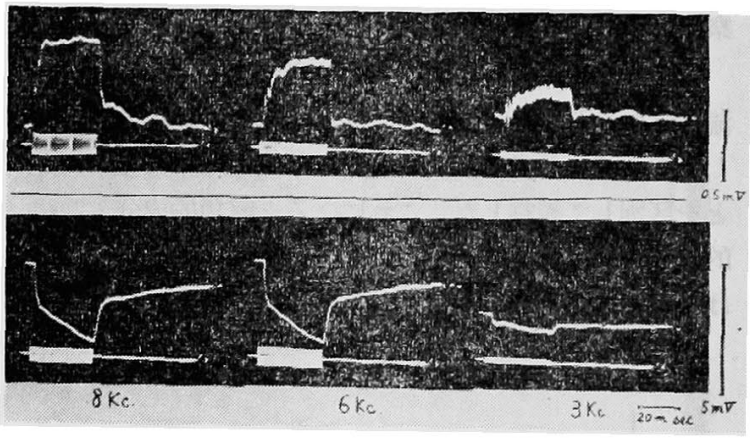

第 4 項 酸素欠圪に上る影製;

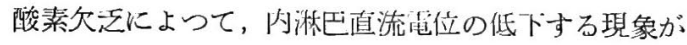
知られているが，この際音刺战による前記電位変動はど のよらに影響されるであろらか. $1000 \mathrm{cps}, 90 \mathrm{db}, 0.4$ 秒 の音刺战を 1 秒 1 们の繰返しで与え乍ら, 人工呼吸器の

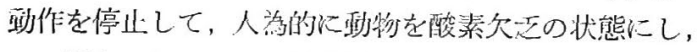
この現象を䚁察した。第8図は队淋巴の直流当位 $75 \mathrm{mV}$ の動物で，2分間の呼吸器動作停止を行い，その際の变 化を記録したものである. 図中黒い革状のもの〉幅は， 上記音刺㦸による亿位変動の振幅であり，この带状の力 ーブの上縁を結んだものが，内情巴直流雪位であり，酸 溸欠乏によつてこの雨者は影響される. 即ち内濰巴直流 電位の低下し炲める顛から音刺战に上る实位变動の拻幅 
第 8 図

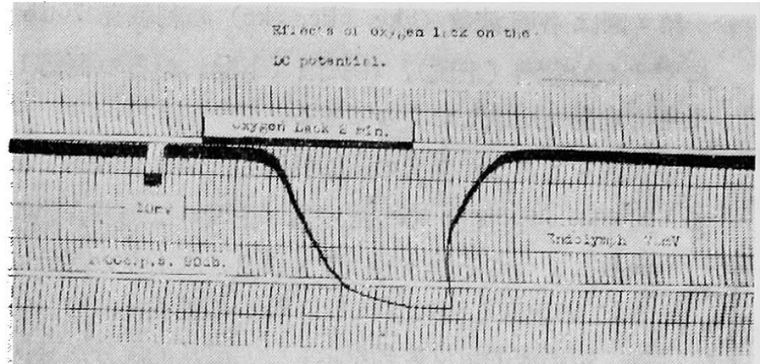

対内淋巴の電位勾配は巡転することになる，この場合音 刺㦸に対する電位変動はどのよらに变るものかと考え て, 内淋巴直流電位の酸素欠乏による変動分を補正し 乍ら，音刺㦸に対する電位変動分のみをオシロスコー プ上で皟察したのが第11 図である。

この記録に見られる如く，高度の陵素欠乏状態に拈 いては，音桙战による電位贸動は逆転することを知る ことができた。

第 10 図

は娍少し始め, 直流電位の低下と共に，その振幅孔平行 して減少するが，約 2 分で，この感度では観察できぬ程' に小さくなる。 この洔期に打いて, 人工呼吸器の動作を 再開始すると, 約 20 秒後から直流位は急激な上算を示 し，この現象の振幅もこれと平行して增加するのが見ら れる．直流電位が 元のレベルを越えて overshoot の見 られる時期に扰いても，この振幅は未だ元の值に回復し ておらず． overshoot の傾向もなく，緩徐な增加を示 し, 人工呼吸器動作再後的 3 分で, 内淋巴直流電位並び に音刺㦸による電位変動の振幅が元の值に民鬼ることが観 察された。

第9 図は酸素欠乏の際に打ける音剌战による内淋巴直 流電位の動きと同時に観察された C M の変化とを比輍 したもので，前者は直角的成分（f）と曲線的成分（d) とを区別して観察した．これによると直角的成分も曲線 的成分も同じょうな低下，恢復を示しているが，CM はや〉異つた変化率を示すことが知られる。

第 9 図

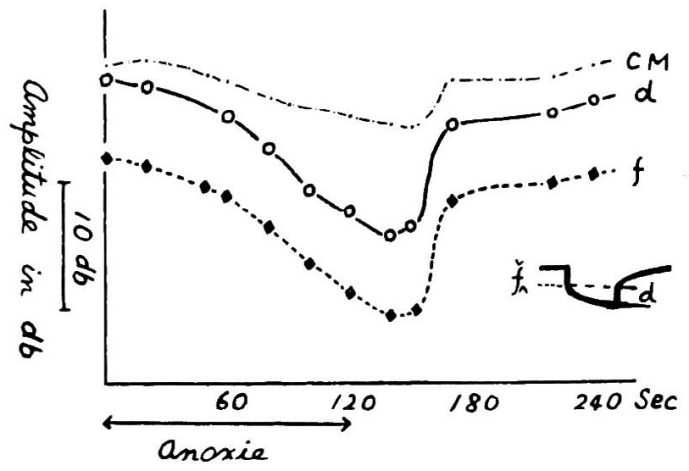

一力以淋巴直流電位は，酸素欠一この時间を延長せしめ る上，第 10 図に示したよらに，約 2 分 30 秒頃から，鼓 兵階外淋巴の西位上引女优下して, negative の他位を

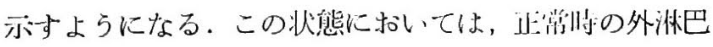

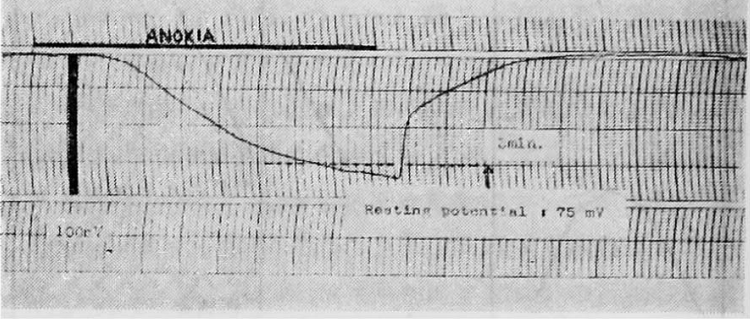

第 11 図
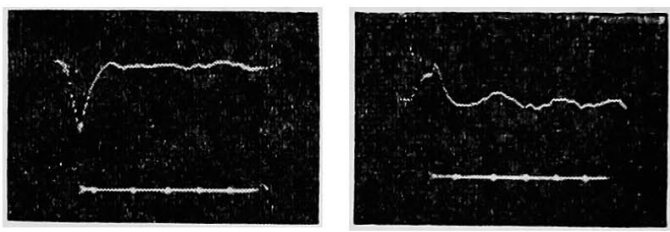

第 4 章 考按

以上述べた如く, 聴器が音によつて束战された場合に は，その刺战時間の長短に拘らずほよ゙刺战時間に一致し て蝸牛内部の直流電位が変動ることを認めた．即ち中央 階の内淋巴においては，その直流電位が低下（あろ条件: 下にあいては上年）し，鼓室階の外湘巴においては，内 淋巴の 電位変動に 対して 鏡像的な変動を示すことを見 た。

1951 年 Békésy は蝸牛内部に 常時存在する直流電位 を発見し，更にこの電位が音刺战によつて変動すること を観察している，彼はこの電位変動を，蝸牛内部の直流 電位が音刺战により低下する現象と考えて，この現象を dc fall と呼んでいる. 第 12 図は彼の成績の引用である が, 800 cps 10 秒間の持綂音で刺战し, 且つ直流增幅器 でこの現象を観察している，第 2 図に示した者者の成績 はこの dc fall の波形と一致するものである.

他方 Davis 等は，音刺㦸に応じて住ずる C M が一

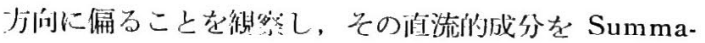
ting Potential と呼んでいる，彼等は剩㦸香の持続时閌 
第 12 図

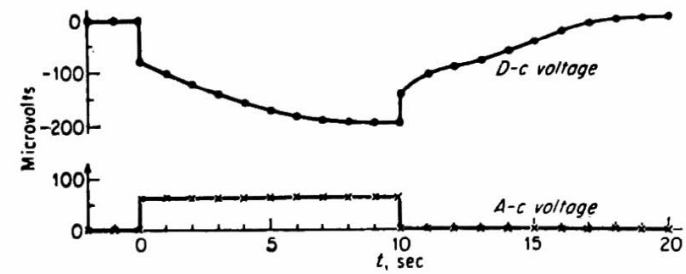

が数 10 ミリ秒と言う短い音 (Pip, Click) で刺㦸し, 且 つ交流增幅器を用いて, この現象を観察しているが, そ の波形は第 13 図に示す则くである.この波形は著者の 倠察方法において, 短い音刺战に対する電位变動を交流 增幅器を介して観察した波形と一致するものである.

第 13 図

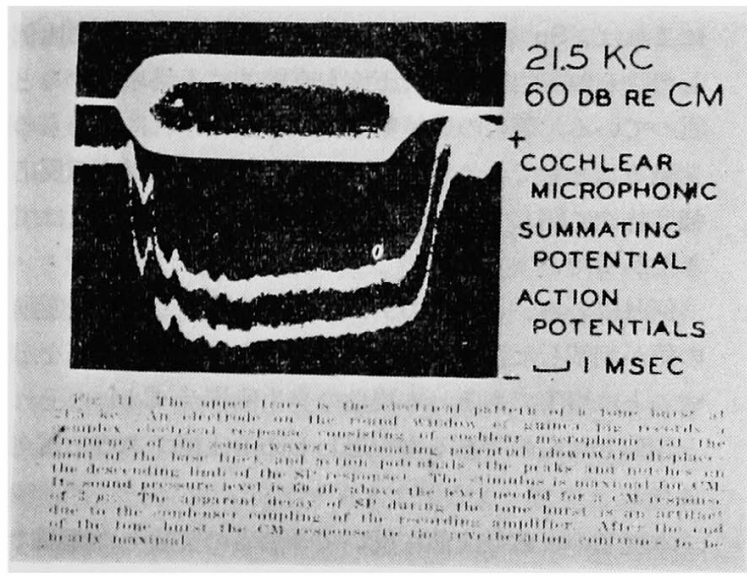

刺㦸音の持継時間を, dc fall の現象のような秒単位 の長さから，SP のようにミリ秒の単位まで，次第に短 雞して観察すると, 上記の現象の波形は, dc fall の波 形から SP の波形へと移行してその間に不連繶な点は 認められない.

このようなことから推して, dc fall と SP とは, 同 一の現象を指していると考えられる．従つて SP の現 象は, dc fall の現象を洔間的にその一部分丈を観察し ているものと考えることができる.

次にこのような音刺軲によつて螖牛内部の直流電位の 变㨽する現象の本態に関する考察を進めて見よう。この 手捗りを得よらとして，省者はこの現象の波形，latency, 強度特性, 内外両淋巴腔より誘導した波形の比較, 更には酸素欠亡の際の内淋巴直流電位の变動との相関関 係などに就いて倠祭した。その絬果既述の则きデータを 得ることができた。
波形並びに latency に就いて。既述の则く，本現象 の波形は，使用せる刺省战の波形の包絡線とほ二似た波 形を呈するものである. 又その latency は C M のそ れと同様に非常に短く測定不能である. 従つてこの電位 変動は, 神経の活動電位とは全く異つたむのである事は 明白である、寧ろこの現象の波形が使用せる刺㦸音の波 形によつて規定され，又その latency が C M に近い 点などを考えると, その発生機構は C M に似たものと 考えられる. Davis が SP の波形の特徴を“C M が 整流又は検波されたよらな波形”之表現しているのもそ のためであろら．更に彼はこのような現象が，基磈膜の 振動により，コルチ器の有毛細胞の毛の部分にshearing motion が生じ, 毛の傾きが一方向に偏るために, 内毛 細胞に主としてこの偏位に一致した電位が発生すると言 ら仮説を述べている，他方 Tenndorf 3) は蝸牛模型夹 験から “高い周波数で且つ強い音圧の音刺㦸によつて， 蝸牛管が非対称的に 偏位する.この物理的な 偏位が, $\mathrm{SP}$ の発生と船接な関係を有するものであろう”と述へ ている.

以上の如き Davis 並びに Tenndorf の仮説は経過時: 間の極めて短い刺㦸音を用いた場合の現象 (SP) の波 形を説明するのには都合が良いけれども, 経過時間の長 い刺战音を用いた場合の現象 (de fall) の波形即ち刺 战中に電位の変動がな撨行し, 又梙战停止後において も response が暫く残ると言う経過を説明することには 困難である. 更に又第 5 図に示した如く, 同波形上に negative 並びに positive の波形が混つて見られる現象 を説明することも困難である。

Békésy は第 12 図に引用した如く, dc fall を指して fatigue and recovery と言ら意味に説明しているけれ ども, 著者の成績によれば内耳度労が起るとは考えられ ぬような弱い音刺㦸に対しても常に観察されるものであ る. 従つてこの説明が妥当とは考えられない、又彼はこ の現象の発生機構に就いては触れていない，但し dc fall と呼んでいることから推して, 蝸牛内部の直流電位 (DC) そのものが変動（低下）方る現象と考えていると 推察できる.

この蝸牛内部の值流䉓位殊に内淋巴の直流䉓位の $\mathrm{Ge}$ nerator に就いては, Békésy, Tasaki4), Davis5), Gisselsson'), Misrahy7) などの研究がある。Tasaki8) は内 淋巴腔において stria vascularis が他の部位に比較し て高い positive の龟位を亦すことを証明した。即ち彼 によつて内淋巴腔の直流静笔位は stria vascularis の 
生活現象の所産であり，このるのから供給されるもので あることを明らか炕した。

このことから, dc fall の現象を Békésy はこの電位 の一部が音刺战によつて消费され， stria vascularis の 機能をむつてこれを補い切れぬ状態が生して，その結果 電位降下を起寸必のと教党，fatigue なる語を用いたの であろう。この上うな仮説は“dc fall の波形”の経過 を説明するには许合のよらに思はれる.しかしここで ある一定条件下（例总ば低音弱音刺战）でこの現象が逆 万向に起る，換言すれば，音刺㦸によつて直流電位が增 加する方向に起る現象を見逃すことができない，この現 象は既に Davis の Sp に関する記戴の中にも見られる ものであるが，上述したよらな Békésy の消費之補充 と言う概念をつては説明し難い，強いて説明するなら ば，一定条件下での音刺㦸の際には，消費以上の補充， 即ら Stria vascularis の機能立進状態が生ずると考党 さるを得なくなる。しかし基磁膜などに比へて振動感受 部位として遥が不適当な位置にある stria vascularss にこのようなことが生ずると想像するのは無理ではある

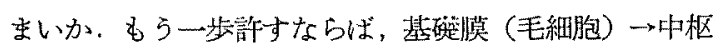
$\rightarrow$ stria vascularis の順烧射寻众しての作用が考え られるけれども, latency が殆ど無に等しいことからこ れを符定することはできない

この点に関する限りに括いては, negative Sp と positive $\mathrm{Sp}$ とは夫タ generator を異にし, negative $\mathrm{Sp}$ は外毛細胞，positive Spは内毛細より発生するとする Davis 等の仮説の方がより多くの妥当性を有するもの之 考えられる。

著者の成績に見られるこのような場合の波形を見ると

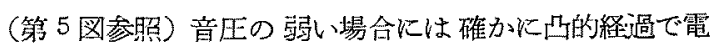
位は基線よりも上算している。一方強い音王に刘しては 逆電位が基線より低下しているのが見られる. Davis が妈刺㦸で $+\mathrm{Sp}$ ，強刺㦸で $-\mathrm{Sp}$ を見たと報告してい るのと一致する.しかしここに示した例の如く - Spに 相当する强刺战の波形も亦凸的な経過を示す場合もある から，単に基線を境にして正負の電位が互に鏡像的に出 現するというような簡単な表現方法をむつてこの問題を 全て論ずることは不可能であると思われる。

強度特性に就いて，著者の成績（第6図）によれば， 電極插入後時間の推移ともに同一強度に対する反応値が 变化するもの小如くである。この図には，測定開始持， 20分後，50分後の值が沙されている。測定開始時の反地

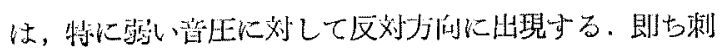

战によつて直流電位が上䑤する現象が見られる（四中 (+）と記入した).この事実は, Davis 並びに Békésy も, $\mathrm{Sp}, \mathrm{dc}$ fall に関する記載の中で認めている. 彼等 は動物が新鮮 (fresh preparation)な場合にこの鸟弱策 による $+\mathrm{Sp}$ が見られると表現としている．著者の成績 からもこの裴現が当つていると思はれるけれども“fresh preparation”のみでは余りに漠然とした表現であるよ らに思かれる，とにかく本現象の反応強度が刺㦸音の強 弱に左右されるのみでなく，他の未细の因子(動物の状 態?)に影響されることは事实の如くであり，興味深い、 現象であると考える。

ここで本現象の強度特性の代表的なる。（第６図（目）） を同時に観察される $\mathrm{CM}$ の強度特性と比較して見ると 互に似たカープを示していることが解る. Davis の発表 によれば， Sp の成績に执いては，刺战音の音圧に比例 して，しか子相当強い音珐迄も直線的に上昇增加すると

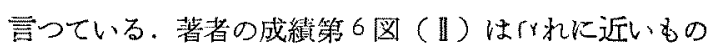
と見ることもできょらが，とにかく強大音に対する反応 強度特性に関しては，完全な成績の一致を見ることはで きなかつた。

何れにしろ，これらのデータを見る将，この電位㚆動 の值が刺战した音の強さとある程度迄直線的な関係を示 すことは事奉である。本現像の発生機構が CM のとれ と類似したものである事を思わしめる成績であると言兄 上う。

本現象の反応最大值比就いて、著者の头駼した筑围で は，90db に対し $8 \mathrm{mV}(1000 \mathrm{cps})$ であつた. Gissels-

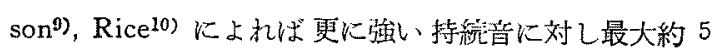
$\mathrm{mV}$ の変動を钼察している. 若し Davis が言うように この電位が, 音王の上笔に従つて，どこ迄も直線的に增 加するものならば，著者の成績から推して，Gisselsson， Rice などの成績はもつと大きい値でなければならない， この点に就いては，動物の状態を考虑して更に檢討が必 要であると洘えられる。

次に内外両淋巴腔より誘導した波形を比較して見る と，一般に両渚の电位多㳩が鏡像的であることを知つ た。この結果はこの電位を発生する部位が，中央階と鼓 室階の間に介在する基䂵膜上にあることる意味するもの であろう。Davis は内外淋巴に打ける Sp の極性にし て著者と同様の結果を示しており，且つ Sp の Generator として其配膛上の毛細胞を考えている，音刺㦸に

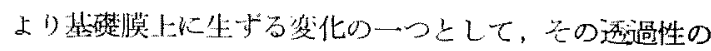
多動を举げることができる，例えば misrahy ${ }^{11)-15) ~ は ~}$ 


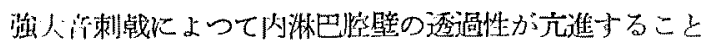
を钼察している，彼の使用した刺战音の音王は非常に強 大なもので，著者の使用した音王とは相当な差があり。 その成紸を著者の成䋶と直ぐ比較することは困難である が，音刺㦸による cochlear partitonの透過性の変動は 本現象の解釈上考虑すべき問题であろう．但しこの現象 を単にイオンの透過性の変動のみで説明しょらといら試 みをるつてしては，既述の - Spに対する + Sp の蛪 釈困難を感ずるであろう。

周波数特性に関して，第 7 図に示した波形の如く，こ の現象の振巾は使用する刺战音の周波数によつて異り。 高い周波数に対して大きいと言うことが知られる。Davis が Sp の成績の中で高い周波数の音刺战に対して， 上り著明に観察されると述べているが，著者の成績と一 致するむのである．その誘導の部位が高音に良く応ずる とされている蝸牛基憷回転部であるために距離的影響が 反映しているとも教えられる。

一力䛠室階の外淋巴に和ける観察では，剌战音の周波 数によつて哄つた波形が見られ，周波数が高くなるにつ れて，刺钱音の波形の包絡線に良く似た波形を呈するこ とは與味あることで本反応の Generator を追求する手 脚りとなる事実ではないかと考えられる。

次に酸素欠乏に際して本現象の变禹が，内淋巴の直流 電位の変動とほざ平行することを知つた．本現象が単に 物理的な機俩だけで発生するものでなく，酸素を必要と する機構，恐らくは組織の生命と関保の深い現象である ことを思わしめる成續である。更に高度の酸素欠壮態 に批いては（この時期に执いては，内淋巴の直流電位 は，外淋巴の電位に比較して negative になる) 本現像 の波形が逆転することが知らた。この成樍は Konishi ${ }^{16)}$ の成績と一致するものであり，又 Davis は酸素久乏時 に逆転することを $\mathrm{Sp}$ の報告に打いて記载している。

波形が逆転する条件として，先に動物の状態と共に刺 战音等に就いて述べたが，酸素欠乏の際の逆転条件は上 述の如く内淋巴の直流電位の減少と関保が深いるので発 現機粠を前者と異にするよらに考学られる．即ら内淋 巴の直流電位との関係がより深いのではないかと思は れる。乙かし乍ら恢復時において内淋巴直流電位には overshoot が見られるけれども，本現僄の振融の恢復に

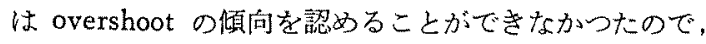
現状の段階で両者の関係に就いてこれ以上論ずることは でさない。

著者は第 3 图に批いて，本現象の波形を直角的経過上

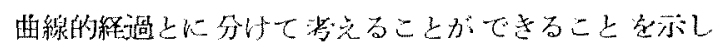
た。これら二つの成分は明確に区別できる場合とできぬ 場合とがある。第4 図に示した波形に括いては，余り明 確に区別でき好れども，第 5 图に示した波形に批いて は，非常に明確に区別することができるこの第 5 図の 波形に拈いては，他の波形に比軦して曲線的な成分だけ が特異な経過を示すことは既述したが，音厈の上算と〉 むに，直角的成分は增加与るのに比較して，その曲線的 成分の变動を見ると，その変䡃值は逆に減少しているこ とも知られる。これらの輙からこの二つの成分は区別し て考劣る可きのであるらと思はれる，この両成分が酸 素欠乏に対して，異つた時間的推移を示与ものではない かと考えて、実験を試みたが，結果は第9図に示した如 きるのであつた。これによるとその变化率に抢いては雨 者共に平行しており，期待した如き成績は得られなかつ た.この成績を C M のそれと比較してみると，低下率 並びにその時間的推移関して C M のそれとはや子異 つている成縝を得た．以上の上うに酸素欠乏に対して は，既述の両成分は共に同じょらな変化態度を示するの であることを知つたが，更に種々の条件下に和いての二 者の関係を追水することも要であると感じる。

以上の考察の如く，音刺戎に上つて蝸牛内直流電位が

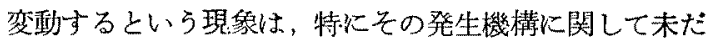
多くの未解決な問題を含しでいると考元られる。立観 的な魮覚と本現象とを比較した場合，聴覚痕労を起す之 は教えられないような芎い音刺战に対してる，本現象が 観察され，刺㦸後において整くの間この刺战効果が残存 すると言うことは，現在の段階で聴感覚に対してこの現 象がいかなる役割を演じているかを論ずることは難し い.しかし内耳に和いてこの上らな現象が観察されると 言うことは事害であり，更にこの上らな電気現象を発生 させる何らかの変化が内耳比じていることも疑いを容 れない所であるうから，音刺战感受機檋を解明する手段 として本現臬についての研究の果す役割は少なくないる のと考学る。

\section{第 5 章 結語}

著者は，純音刺战による蝸牛内直流電位の变動を観察 し, 次の如き経果を得た。

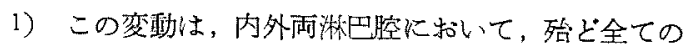
周波数の音刺㦸に対し，その刺战の長短に拘ら寸゙，䘽察 されるものである。

2）内淋巴腔における変動は，一般に内淋巴直流電位 の減少する方向に起るものである，又その経過は，著者 
の使用した音王（90db 以下）においては，音刺战の開 始と共に值角的に低下し，以後山的な曲線的経過をもつ

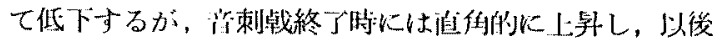

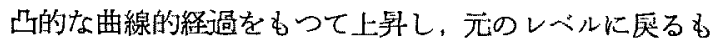
のである.しかし正常時に批いて，低い周波数の骋い音 压の刺敁音に対して時に，内淋巴直流電位の上笔する方 向に起ることも観察される。この時の経過の特徵は，音 刺㦸中凸的経過を示すことである。

3)この現橡の latency は CM と同样に短く測定不 可能であつた。

4）その変動值は，弱い音王においては，音王の上笔 に比例して直線的に增加するが，約 $75 \mathrm{db}$ 以上に颃いて は，增加率は減少し，非直線約增加を示す 又刺㦸音の 周波数の高い程大きな变動値を示す.

5）外淋巴腔における変動は，内淋巴腔における万向 とは反対方向をとり，その值は内淋巴空に和ける值の約 1/8である. その経過山剌幟音の周波数によつて異り， 低い、周波数に対しては，内淋巴腔のそれと似るが，高く なると $(8000 \mathrm{cps}$ 以上) 次第に刺㦸音の波形の包絡線に ほつ一致しな経過を示すようになる。

6）酸素欠乏による影響は，内淋巴直流電位の低下に 伴い，音刺皒による電位变動の振幅もほざこれに平行し て低下する。酸素欠之方が高度になり，内淋巴控の電位が 外淋巴腔のそれに比べ負になる時期にほぶ一致して，音 刺㦸による䉓位变動む，その偏位の方向が逆忶するのが 観察された。呼呚の再開始に上り，酸素欠乏の状態が恢 復する過程においては，内す巴直流電位の恢復にほ心゙平 行して既述の電位变動も恢復するのが認められた，但し 恢復時において内淋巴直流電位には一時的に元のレベル 以上の電位を示寸現泉 (overshoot) が認められたが, 音制战による電位変動の 振巾には overshoot の傾向は 認め難い。

\section{文献}

1) Davis, H. et al.: The excitatory process in the cochlea. Proc Nat. Acad. Sci. 36, 580, 1950.

2) Békésy, G.V; D.C. potentials and energy balance of the cochlear partition. J. Acoust, Soc. Am. 23, $576,1951.3$ 3) Tenndorf, J.: Shearing motion in seala media of cochlear models. J. Acoust. Soc. Am. 32, 238, 1960. 4) Tasaki I. et al.: Exploration of cochlear potential in guinea pig with a microelectrode, J. Acoust. Soc Am. 27, 765, 1954.

5) Davis, H. et al.: Modifications of cochlear po- tentials produced by streptomycin poisoning and by extensive venous obstruction, Laryngoscope $68,596$. 1958. 6) Gisselsson, L.: Neue Problem des Cochleaeffektes. Arch. Ohr-, Nas-, u, Kehl-, Heilk 167, $274,1955 . \quad 7)$ Misrahy, G.A. et al.: Effects of localized hypoxia on the electrophysiological activity of cochlea of the Guinea pig, J. Acoust. Soc. Am. 30, 705, 1958 . 8) Tasaki I et al.: Stria vascularis as source of endocochlear potential. J. Neurophysiol. 22, 149, 1959. 9) Gisselsson L.: Die elektriscoen Potentiale des Innenohres. Arch. Ohr-, Nas-, u, Kehl-Heilk. 177, 45, 1960 , 10) Rice, E.

A. et al.: Studies on the endolym phatic d,c, potential of the guinea pig's cochlea J.A coust. Soc. Am. 33, 922. 1961. 11) Misrahy G.A. et al: Endoly. mphatic oxygen tension in the cochlea of the guinea pig. J. Acoust. Soc. Am. 30, 247. 1958.

Misryhy, G.A. et al.: Changes in cocolear endoly. mphatic oxygen availibility action potential, and microphonics during and following asphyxia, hypoxia, and, exposure to loud sounds J. Acoust. Soc. Am. 30, 701, 1958. 13) Misrahy, G.A. et al.: Genesis of endolymphatic hypoxia following acou stic trauma J. Acoust Soc. Am. 30, 1082, 1958.

14) Misrahy, G.A. et al.: Electrical properties of wall of endolymphatic spacl of the cochlea, Am. J. Physiol 194, 396, 1958. 15) Misrahy, G.A. et al: Effects of intense sound hypoxia and Kanamycin on the permiability of cochlear partitions Ann. Otol, 70, 570. 1961. 16) Konishi, T. et al.: Effect of anoxia on cochlear potentials J. Acoust. Soc. Am. 33, 349. 1961. 17) Békésy, G.V.: Gross lcoalization of the place of origin of the cochlear microphonics J. Acoust. Soc. Am. 24, 399, 1952.18 ) Davis, $H$, et al.: Cochlear potentials after intracochlear injections and anoxia Fed. Proc. 14, 35, 1955. 19) Vosteen, K.H.: Neue Aspekte zur Biologie und Pathologie des Mnenohres. Arch Ohr-, Nas-, u, Kehl-, Heilk. 178, 1961 20) Riesco mac Clure et al: Ante-mortem failure of the aural microphonic in the Guinea pig Proc. Soc. Exp. Biol \& med 71, 158, 1949. 21) Goldstein R.: Analysis of summating potential in cochlear responses 
Am. J. physiol 178, 331, 1954. 22) Davis H. et al: Summating potentials of the cochlea. Am. J.

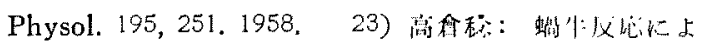

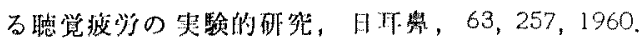

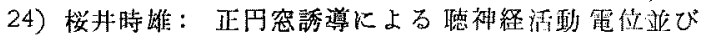
KSummating potential の研究，日耳與，64, 1765， 1961. 25) Békésy, G.V.: Experiments in Hearing Mac. Graw.Hill Book Comp. 1960.

粉を終るに臨み御指導业びに御校閲を睗つた恩師 立木襄教授に梁謝すると共に，研究に際し常に微便 宜，御㮩撻を頂いた河本和友助教授，実験に際し終

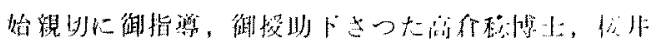

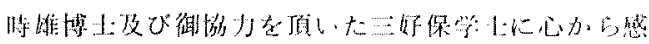
㴬の意を社します

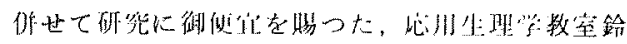
木泰三教授亚びに丁学部城卢健一助教授に感謝致し ます

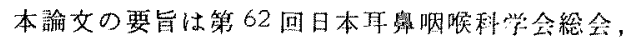
第 5 回，第6 回日本オージャギー学会，第 11 回

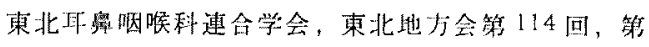
115 回例会に批いて登装した。

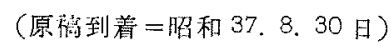

